\title{
SEED GERMINATION AND SEEDLING FORMATION OF Eugenia stictopetala (MYRTACEAE) UNDER DIFFERENT ENVIRONMENTAL CONDITIONS
}

\author{
Richard Matheus Fernandes ${ }^{1}$, Clara Anne de Araujo Abreuํㅜ José Carlos Pina², Ademir Kleber Morbeck \\ de Oliveira ${ }^{2 *}$ \\ ${ }^{1}$ University Anhanguera-Uniderp, Biological Sciences, Campo Grande, Mato Grosso do Sul, Brazil - \\ ricfernandes.richard@gmail.com,clara1clara@hotmail.com \\ ${ }^{2}$ University Anhanguera-Uniderp, Graduate Program in Environment and Regional Development, Campo Grande, Mato Grosso \\ do Sul, Brazil - josecarlospina@gmail.com, akmorbeckoliveira@gmail.com*
}

Recebido para publicação: 04/10/2018 - Aceito para publicação: 14/05/2019

\begin{abstract}
Resumo
Germinação de sementes e formação de plântulas de Eugenia stictopetala (Myrtaceae) em diferentes condições ambientais. A espécie Eugenia stictopetala, conhecida como cambucá ou língua-de-cachorro, é encontrada em áreas de Cerrado, produz frutos em forma de drupas, pretos quando maduros e muito consumidos pela fauna. Apesar de seu potencial de uso, não existem informações sobre seus processos germinativos e por este motivo, objetivou-se avaliar sua germinação e formação de plântulas em diferentes temperaturas, além de sua germinação após armazenamento inicial. Sementes recém-coletadas em área de Cerrado foram avaliadas em seis temperaturas $\left(20,25,30,35,20-30\right.$ e $\left.25-35^{\circ} \mathrm{C}\right)$ e após 35 dias de armazenamento em diferentes condições ambientais, em delineamento inteiramente casualizado. Os resultados obtidos indicaram que as sementes possuem alto teor de água, e a temperatura de $30^{\circ} \mathrm{C}$ sendo a mais adequada para a germinação e formação de plântulas. Após armazenamento, ocorre perda do teor de água, levando a uma redução nas taxas de germinação, indicando uma característica de sementes recalcitrantes.

Palavras-chave: Cerrado, temperatura ideal de germinação, cambucá, sementes recalcitrantes.
\end{abstract}

\begin{abstract}
The species Eugenia stictopetala, known as "cambucá" or dog-tongue, is found in areas of Cerrado and produces fruits in the form of drupe, black when mature and much consumed by the fauna. Despite its potential for use, there is no information about its germination processes and for this reason, the objective of this work was to evaluate its germination and seedling formation at different temperatures, besides its germination after initial storage. Newly collected seeds from the Cerrado area were evaluated at six temperatures $(20,25,30,35$, 20-30 and $25-35{ }^{\circ} \mathrm{C}$ ) and after 35 days of storage in different environmental conditions in a completely randomized design. The results indicated that the seeds have a high water content and the temperature of $30{ }^{\circ} \mathrm{C}$ being the most suitable for germination and seedling formation. After storage, loss of water content occurs, leading to a reduction in germination rates, indicating a characteristic of recalcitrant seeds.

Keywords: Cerrado, ideal germination temperature, cambucá, recalcitrant seeds.
\end{abstract}

\section{INTRODUCTION}

The Brazilian territory is known to have in its different biomes a great variety of fruit trees still little studied, but with potential of use. The species Myrtaceae, a family known for the presence of plants with commercial use, such as guava (Psidium guajava L.) and jabuticaba (Myrciaria cauliflora (Mart.) O. Berg.), stand out in this respect. Several species of the family present potential for use in commercial orchards, and it may be mentioned "cerejeira-do-mato" (Eugenia involucrata DC.), "uvalheira" (Eugenia pyriformis Cambess.), "guabirobeira" (Campomanesia xantocarpa O. Berg), "araçazeiro" (Psidium cattleyanum Sabine) (DANNER et al., 2010) and "cambucá" (Eugenia stictopetala Mart. ex DC.), for example. However, there are few studies about their reproductive processes, making it difficult their use.

Many of these species are threatened by the anthropization processes advancement of natural areas, before their potential of use is known. One of the Brazilian biomes with great diversity and strongly threatened by the advance of agricultural activities is the Cerrado, considered the second largest in South America, occupying approximately $24 \%$ of the Brazilian territory (ROCHA et al., 2011).

In this biome, considered a hotspot, a large number of fruit species occurs and among those is Eugenia stictopetala, which has a shrub shape, with fruiting in the months of June and July and fruits in the form of black drupe (when mature), consumed by the fauna.

FLORESTA, Curitiba, PR, v. 49, n. 4, p. 869 - 876, out/dez 2019.

Fernandes, R. M. et.al. 
Species with potential use need to be studied for different reproduction parameters. For their propagation, tests are required to indicate the best germination conditions of their seeds and if they maintain their viability after collection. Thus, research on germination and seedling formation are fundamental so that species with potential of use can be better known.

Regarding the seed storage, it can indicate the characteristics of the species and whether their seeds can be stored without loss of viability, and/or the conditions necessary to maintain their vigor. In general, once the storage is properly applied, it guarantees the germination and reduction of the seeds deterioration, thus preserving their physiological quality.

The use of different temperatures is fundamental to identify the best conditions for the seedlings germination and initial growth, where the temperature acts directly in the metabolic processes, for example, accelerating or slowing the chemical reactions and in the gases absorption that induce a greater or lesser production of germinated seeds. However, the seeds present variable behaviors and although there is no ideal temperature, authors such as Brancalion et al. (2010) argue that for most Brazilian tree species, the temperature of $25^{\circ} \mathrm{C}$ is the most favorable, followed by $30{ }^{\circ} \mathrm{C}$. In this range the optimum temperature would be found, with a higher germination percentage in a short period of time.

Despite the importance of studies aimed at seeds of species with potential use, the information on Eugenia stictopetala is still scarce and in therefore, the objective was to analyze the seed germination and seedling formation at different temperatures, besides the seeds behavior after a period of 35 days of storage.

\section{MATERIAL AND METHODS}

In August 2016, fruits of Eugenia stictopetala were collected in the region of Taboco, Corguinho - Mato Grosso do Sul, directly from the shrubs, with the help of pruning shears or manually. The collected material was placed in paper bags and transported to the Interdisciplinary Laboratory for Research in Environmental and Biodiversity Systems, University Anhanguera-Uniderp, Campo Grande, Mato Grosso do Sul.

In the laboratory, the seeds were manually removed and surface disinfected by immersion in sodium hypochlorite $(2 \%)$ for three minutes and then washed in running water for one minute, eliminating predated or malformed seeds. The water content was evaluated using the oven drying method at $105 \pm 3{ }^{\circ} \mathrm{C}$ for 24 hours (BRASIL, 2009), with four replicates of 25 seeds. Subsequently, the seeds were divided into two lots, according to the established experiment. The design was completely randomized, with four replicates of 25 seeds per transparent plastic boxes.

\section{Experiment I}

In the first part, the best germination conditions were evaluated, using six temperatures (constant, 20, 25, 30 and $35^{\circ} \mathrm{C}$ and alternating, 20-30 and $\left.25-35^{\circ} \mathrm{C}\right)$. The seeds were placed in transparent plastic boxes $(11 \mathrm{x} 11 \mathrm{x}$ $3.5 \mathrm{~cm}$ ), lined with 2 sheets of germitest paper, moistened with distilled water in the ratio 2.5 times the weight of the dry paper. When necessary, the paper was moistened again. The evaluation was daily, being considered germinated the seeds that presented primary root of $2 \mathrm{~mm}$ in length (botanical germination criterion).

The germination percentage (number of germinated seeds), relative frequency of germination and germination vigor were quantified (speed germination index, calculated by formula SGI $=\sum\left(\mathrm{n}_{\mathrm{i}} / \mathrm{t}_{\mathrm{i}}\right)$, where $\mathrm{n}_{\mathrm{i}}=$ number of seeds germinating at time " $\mathrm{i}$ " and, $\mathrm{t}_{\mathrm{i}}=$ time after test installation, unit being dimensionless; and, mean germination time, calculated by the formula MGT $\left.=\left(\sum \mathrm{n}_{\mathrm{i}} \mathrm{t}_{\mathrm{i}}\right) / \sum \mathrm{n}_{\mathrm{i}}\right)$, where $\mathrm{n}_{\mathrm{i}}=$ number of seeds germinated per day and, $\mathrm{t}_{\mathrm{i}}=$ incubation time, with unit in days).

Due to the beginning of the necrosis process of the seedlings root system formed in the germination chamber, they were evaluated after 35 days of testing (plants formed after this period were not measured, computing only those germinated until the end of the experiment at 63 days). The length of the primary root (seedling collar to the meristematic apex of the root system, in $\mathrm{mm}$ ) and aerial part (seedling collar to the apex of the apical meristem, in $\mathrm{mm}$ ) were analyzed using a digital caliper. The dry mass was obtained using the root system and the aerial part from length measurement, stored in Kraft ${ }^{\circledR}$-type paper bag, identified and kept in a forced ventilation oven at $40{ }^{\circ} \mathrm{C}$ for 36 hours. Afterwards, they were weighed individually on analytical balance, with results expressed in grams (mean).

After the end of the experiment, the non-germinated seeds were submitted to the test of viability of $1 \%$ tetrazolium in aqueous solution (BRASIL, 2009), with seeds placed in dark plastic boxes between two sheets of paper towel, kept in the dark at temperature of $25^{\circ} \mathrm{C}$, by 12:00 hours. Then, sectioned and evaluated by observation in stereomicroscope.

Experiment II 
A parcel of the seeds, after superficial disinfection, was divided into four groups: stored at laboratory room temperature ( 1 - paper bags and 2 - semipermeable plastic bags) and, in a cold chamber (3 - paper bags and 4 - semipermeable plastic bags) at $8{ }^{\circ} \mathrm{C}$ and $60 \%$ humidity.

After the temperature identification with higher germination rate, lower MGT and better seedling size in experiment $\mathrm{I}\left(30{ }^{\circ} \mathrm{C}\right.$ constant), germination tests were carried out after storage (35 days), following the same procedures described in the previous experiments.

The germination percentage (number of germinated seeds) and vigor of germination (speed germination index - SGI and mean germination time - MGT) were also evaluated daily. After the end of the experiment, the non-germinated seeds were submitted to the test of viability of $1 \%$ tetrazolium in aqueous solution (BRASIL, 2009), same procedure adopted of the experiment I.

Statistical analysis

The data were submitted to analysis of variance and, when significant, the means compared by the Tukey test $(5 \%)$ by Software Assistat Version 7.7 beta (SILVA; AZEVEDO, 2016), being the tests of normality and homogeneity of variances carried out.

\section{RESULTS}

The analysis of the water content indicated, for newly collected seeds, $52 \%$ of humidity; after one month of storage the following values were found: in semipermeable plastic bag, cold chamber, $46.3 \%$ and room temperature, $47.2 \%$; in paper bag, cold chamber, $43.5 \%$ and room temperature, $40.7 \%$. On average, there was an $8 \%$ reduction between collection and storage.

The relative frequency of germination was not synchronized, having an heterogeneous distribution along the incubation time (Figure 1), with a series of temporal variations, mainly for the best germination temperatures, 25,30 and $20-30{ }^{\circ} \mathrm{C}$. On the other hand, 20,35 and $25-35^{\circ} \mathrm{C}$ presented little variation, with the germination peaks concentrated in a short period of time.
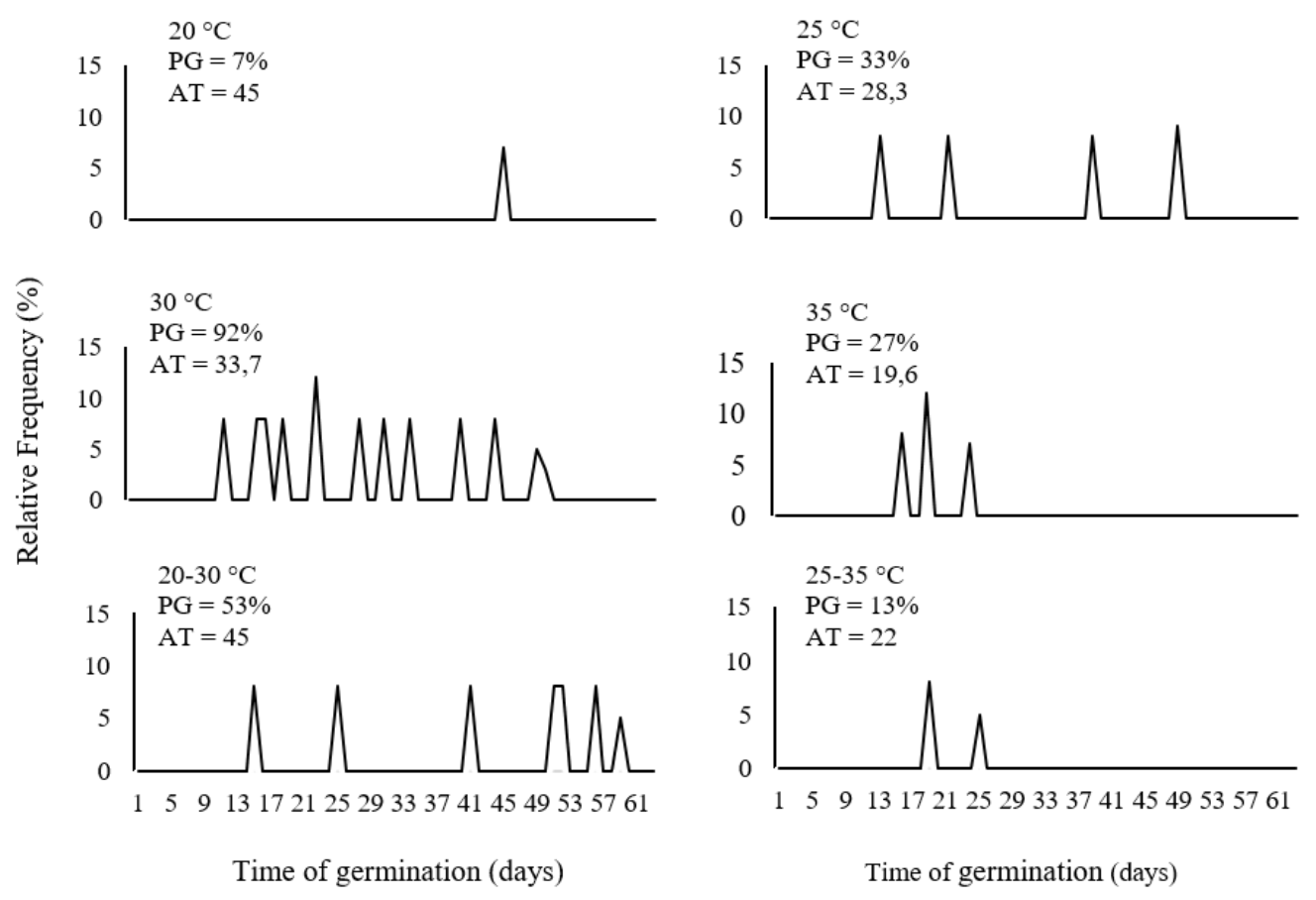

Figure 1. Relative frequency of germination of Eugenia stictopetala in different temperatures $(\mathrm{PG}=$ percentage of germination, AT = average time).

Figura 1. Frequência relativa de germinação de Eugenia stictopetala em diferentes temperaturas $(\mathrm{PG}=$ percentagem de germinação, $\mathrm{TM}=$ tempo médio).

Concerning the germination rate, the best was obtained using the temperature of $30{ }^{\circ} \mathrm{C}$, which also provided the best SGI. Regarding MGT, the best results occurred at 35 and $25-35^{\circ} \mathrm{C}$. Temperatures of $20,25,35$ 
and $25-35{ }^{\circ} \mathrm{C}$ showed more than half of the embryos killed at the end of the experiment. The lowest number of dead embryos was found at $30^{\circ} \mathrm{C}$ (Table 1$)$.

Table 1. Germination (G\%), speed germination index (SGI) and mean germination time in days (MGT) and number of viable and dead embryos in seeds of Eugenia stictopetala in different temperatures.

Tabela 1. Germinação, índice de velocidade de germinação (IVG), tempo médio de germinação (TMG) em dias e número de embriões viáveis e mortos em sementes de Eugenia stictopetala em diferentes temperaturas.

\begin{tabular}{|c|c|c|c|c|c|}
\hline Temperatures $\left({ }^{\circ} \mathrm{C}\right)$ & Germination (\%) & SGI & MGT (days) & Viable seeds & Dead embryos \\
\hline 20 & $7 \mathrm{e}$ & $0.18 \mathrm{e}$ & $45 \mathrm{c}$ & $20 \%$ & $73 \%$ \\
\hline 25 & $33 \mathrm{c}$ & $1.10 \mathrm{c}$ & $28.3 \mathrm{~b}$ & $10 \%$ & $57 \%$ \\
\hline 30 & $92 \mathrm{a}$ & $4.34 \mathrm{a}$ & $33.7 \mathrm{~b}$ & $2 \%$ & $6 \%$ \\
\hline 35 & $27 \mathrm{c}$ & $1.46 \mathrm{bc}$ & $19.6 \mathrm{a}$ & $2 \%$ & $71 \%$ \\
\hline $20-30$ & $53 \mathrm{~b}$ & $1.77 \mathrm{~b}$ & $45 \mathrm{c}$ & $7 \%$ & $40 \%$ \\
\hline $25-35$ & $13 \mathrm{~d}$ & $0.74 \mathrm{~d}$ & $22 \mathrm{a}$ & $6 \%$ & $81 \%$ \\
\hline
\end{tabular}

Means followed by the same letter in the column do not differ significantly by the Tukey test at 5\% probability.

Regarding the initial seedlings growth (Table 2), again the temperature of $30^{\circ} \mathrm{C}$ was the most adequate, followed by $20-30{ }^{\circ} \mathrm{C}$.

Table 2. Initial seedling development of Eugenia stictopetala in different temperatures.

Tabela 2. Desenvolvimento inicial de plântulas de Eugenia stictopetala em diferentes temperaturas.

\begin{tabular}{ccccc}
\hline $\mathrm{T}^{\circ} \mathrm{C}$ & Root weight $(\mathrm{g})$ & Stem weight $(\mathrm{g})$ & Root length $(\mathrm{mm})$ & Stem length $(\mathrm{mm})$ \\
\hline 20 & $0.0011 \mathrm{c}$ & $0.0005 \mathrm{~cd}$ & $38.2 \mathrm{c}$ & $7.3 \mathrm{c}$ \\
25 & $0.0016 \mathrm{~b}$ & $0.0006 \mathrm{bc}$ & $28.8 \mathrm{c}$ & $8.4 \mathrm{c}$ \\
30 & $0.0026 \mathrm{a}$ & $0.0012 \mathrm{a}$ & $56.6 \mathrm{a}$ & $23.1 \mathrm{a}$ \\
35 & $0.0010 \mathrm{c}$ & $0.0003 \mathrm{~d}$ & $35.6 \mathrm{c}$ & $5.5 \mathrm{c}$ \\
$20-30$ & $0.0025 \mathrm{a}$ & $0.0009 \mathrm{~b}$ & $48.8 \mathrm{~b}$ & $17.9 \mathrm{~b}$ \\
$25-35$ & $0.0009 \mathrm{c}$ & $0.0002 \mathrm{~d}$ & $29.5 \mathrm{c}$ & $4.3 \mathrm{c}$ \\
\hline
\end{tabular}

Means followed by the same letter in the column do not differ significantly by the Tukey test at $5 \%$ probability.

Seed germination, after one month of storage (Table 3), indicated reduction of SGI and increase of MGT (loss of vigor), with germination rate being reduced by $22.9 \%$, in relation to newly collected seeds. The best storage condition was obtained at room temperature, plastic packaging, with better germination rate and vigor. The nongerminated seeds, under all storage conditions, were not viable, presenting dead embryos.

Table 3. Germination, vigor of seeds (Speed Germination Index (SGI) and Mean Germination Time (MGT) in days) and number of dead embryos in seeds of Eugenia stictopetala at a temperature of $30{ }^{\circ} \mathrm{C}$ after 35 days storage under different environmental conditions.

Tabela 3. Germinação, vigor de sementes (Índice de Velocidade de Germinação - IVG e Tempo Médio de Germinação - TMG, em dias) e número de embriões mortos em sementes de Eugenia stictopetala na temperatura de $30{ }^{\circ} \mathrm{C}$ após 35 dias de armazenamento em diferentes condições ambientais.

\begin{tabular}{ccccc}
\hline Storage location and involucre & G $(\%)$ & SGI & MGT (days) & Dead embryos \\
\hline Laboratory, paper & $27 \mathrm{c}$ & $0.18 \mathrm{c}$ & $23.8 \mathrm{a}$ & $73 \%$ \\
Laboratory, plastic & $67 \mathrm{a}$ & $0.48 \mathrm{a}$ & $22.5 \mathrm{a}$ & $33 \%$ \\
Cold chamber, paper & 0 & 0 & 0 & $100 \%$ \\
Cold chamber, plastic & $47 \mathrm{~b}$ & $0.26 \mathrm{~b}$ & $27.1 \mathrm{a}$ & $53 \%$ \\
\hline
\end{tabular}

Means followed by the same letter in the column do not differ significantly by the Tukey test at $5 \%$ probability.

\section{DISCUSSION}

The high value found for the water content indicates a characteristic of recalcitrant species, and the seeds are not tolerant to dissection. Several seeds of the species of the genus Eugenia are considered recalcitrant, such as E. bimarginata DC., with $47 \%$ water content, according to a study by Salomão et al. (2003).

In relation to storage, the highest water content was obtained when using semipermeable plastic bags at ambient temperature and cold chamber, which are more adequate to avoid a greater loss of humidity. This factor is due to the fact that plastic is a more effective barrier to avoid water vapor diffusion than paper. The water contente maintenance by packing in plastic bags allows the maintenance of the seeds viability for a longer period of time, being better for storage when compared to the paper bag. 
The relative germination frequency, distributed over a long period of time in the two best germination conditions ( 30 and $20-30{ }^{\circ} \mathrm{C}$ ), suggests an adaptation of the species to environments with water seasonality, such as the Cerrado, conditioning the seeds, in some time, to find favorable geminar conditions, favoring the seedlings establishment.

According to Brancalion and Marcos Filho (2008), this type of behavior is important for the distribution of germination, providing greater efficiency in the seedlings establishment, since they can find suitable conditions for their establishment, at the most favorable time. Oliveira et al. (2014), evaluating seeds of Miconia albicans (Sw.) Triana, collected in Cerrado area, also showed a germination with a temporal distribution of several days (over 15), correlating MGT with the climatic variations of the collection site, subject to periodic water stresses.

Regarding the germination rate, the best results were obtained at $30{ }^{\circ} \mathrm{C}$. High temperatures, up to a certain limit, can accelerate the germination process, reducing the time for germination, but they may also lead to the death of a larger number of embryos due to protein denaturation, which may have occurred for the seeds of the species, according to the low germination rates and the unviable embryos observed at temperatures of 35 and 25 $35{ }^{\circ} \mathrm{C}$ (Table 1).

The lowest temperatures, 20 and $25{ }^{\circ} \mathrm{C}$, were also not suitable for the seeds of the species, generating small germination rates. Although part of the seeds could still be viable, their lower water content at the time of the tests could cause damage to the embryos, impeding the complete seedlings formation, especially taking into account the recalcitrant characteristic of the studied seeds. The obtained data indicated that seeds of this species may be low tolerant to water loss and sensitive to low temperatures, justifying the lowest germination rates at 20 ${ }^{\circ} \mathrm{C}$, for example (Table 1).

It is known that inadequate temperatures can lead to a reduction in total germinated seeds, affecting the vigor and/or the average germination time. Nonogaki et al. (2010) and Bewley et al. (2013) explain that seeds generally may exhibit different behaviors, such as (1) not germinating at lower temperatures, (2) accelerating the germination process, according to the increase in temperature, when they reach the infra-optimal range; (3) decreasing the germination velocity as the temperature increases in the supra-optimal range; and, (4) not germinating when the temperature is too high (maximum temperature). These effects are correlated to changes in the structure of certain molecules, mainly proteins and lipids, which are involved in chemical reactions during the germination.

There is a dependence between the germination speed and the temperature, in which the lower the temperature, the longer the time so that the seeds germinate and the lower the total percentage of germination. The kinetic energy contained in the seeds changes in response to temperature changes, and this factor affects the diffusion pressure, interfering in the metabolic activities; thus, hydration occurs less rapidly at lower temperatures, because it is a physical process (CARDOSO, 2009). Evaluating seed germination of Ormosia arborea (Vell.) Harms, Oliveira et al. (2016) indicated that the tested lower temperature, $20{ }^{\circ} \mathrm{C}$, affected negatively the germination process, in correlation with the seeds kinetic energy decrease, a result similar to that found by this work.

The best result obtained for Eugenia stictopetala would not be within the expected for the species of the Cerrado biome, according to Brancalion et al. (2010), where there is a higher concentration of the indicated as optimal temperatures around $25{ }^{\circ} \mathrm{C}$, being that usually these temperatures are related to the region of the species origin.

On the other hand, other species of the genus Eugenia, E. involucrata DC. ("cereja"), E. uniflora L. ("pitanga") and E. brasiliensis Lam. ("grumixama"), also presented a high germination rate at $30{ }^{\circ} \mathrm{C}$ (Silva et al., 2005). Whereas, Salomão et al. (2003) report that the temperature of $25{ }^{\circ} \mathrm{C}$ was the most adequate for $E$. bimarginata, whereas seeds of E. dysenterica DC. germinate well in the range from 20 to $35{ }^{\circ} \mathrm{C}$ or $20-30{ }^{\circ} \mathrm{C}$ and other species of the same family, such as Blepharocalyx salicifolius (Kunth) O. Berg. and Campomanesia adamantium (Cambess.) O. Berg. at $25^{\circ} \mathrm{C}$. Gomes et al. (2016) found that for Campomanesia xanthocarpa $\mathrm{O}$. Berg the ideal temperature is $20-30$ or $25^{\circ} \mathrm{C}$; in contrast, for E. involucrata and E. pyriformis Camb., $25^{\circ} \mathrm{C}$.

The species have their temperature range more adequate to the germination associated to the regions of origin. Thus, taking into account that the seeds of Eugenia stictopetala were collected in Cerrado areas, it was expected that higher temperatures were adequate, which occurred at $30^{\circ} \mathrm{C}$. The species germinates with greater vigor in a narrow temperature range, being considered estenothermic, a factor probably related to the temperatures of the collection site. The non-germinated seeds, in the end, presented the majority of the embryos dead, demonstrating the inadequacy of the evaluated temperatures (Table 1). Lopes and Franke (2011), studying seeds of Lotus subbiflorus Lag. also observed this situation, in which they considered the stenothermic species seeds. In other words, unable to tolerate large thermal variations, with inadequate temperatures leading to loss of viability and the authors correlating such event with the place where the species grows.

FLORESTA, Curitiba, PR, v. 49, n. 4, p. 869 - 876, out/dez 2019.

Fernandes, R. M. et.al. 
On the other hand, the alternating temperature of $20-30{ }^{\circ} \mathrm{C}$ presented the second best rate, again indicating that $30{ }^{\circ} \mathrm{C}$ exerts a positive influence on the primary root emission. Many of the seed species that germinate at alternate temperatures present this type of adaptation related to the environment in which they are installed, such as clearings in forests, where the temperature variations are more pronounced.

According to Bewley et al. (2013), alternating temperatures are related to the alteration in the balance of promoter and/or inhibitory substances of the germination, facilitating the germinative process. Its influence can be common in species of dry zones or of altered environments, leading to the germination when the clearings formation occurs, as reported by Liu et al. (2013), where the seeds of different species are benefited by the temperature variations, germinating faster. This temperature range, $20-30{ }^{\circ} \mathrm{C}$, as well as $30{ }^{\circ} \mathrm{C}$, is also considered optimal because it is closely associated with the biochemical reactions responsible for regulating metabolism during germination and primary root emission (BEWLEY et al., 2013).

Another factor observed for Eugenia stictopetala is the small seeds vigor, demonstrated by low SGI and high MGT. In work with Eugenia involucrata, Gomes et al. (2016) also indicated low vigor. Whereas, Costa et al. (2017), with Eugenia pyriformis, found mean values of SGI of 1.5, similar to that found for E. stictopetala and MGT of 17.7, higher.

Brancalion and Marcos Filho (2008) correlate the lowest vigor to a germination distribution over time, that is, for longer periods, a strategy that can allow the seedlings to settle in certain moments, in appropriate places. This distribution favors species that are found in regions of seasonal climate, such as the Cerrado, where rainfall is usually seasonal. It was observed in the field that Eugenia stictopetala has fruiting in August/September (ripe fruits), end of the period of drought in the region, with seed dispersal occurring in September. Thus, seed distribution would occur at the beginning of the rainy season, from September/October, when rains are still irregular. Therefore, a higher MGT would be favorable for the seeds to find, at some point, soil moisture suitable for their germination and seedling formation.

Initial seedling growth was more vigorous at $30{ }^{\circ} \mathrm{C}$, followed by $20-30{ }^{\circ} \mathrm{C}$, with better development of roots and stems in both length and weight. In this case it can be said that these temperatures influenced positively both germination and seedling formation of Eugenia stictopetala (Table 2). However, the data obtained do not fully reflect the seedling formation process, because the long time of its growth in the paper substrate led to an early roots necrosis, shortening the experiment time.

Regarding the means of length and weight, there is a growth difference between the aerial and underground, at all temperatures tested, in which the roots grow faster, which would be expected. Authors such as Periotto and Gualtieri (2017) suggest that Cerrado plant species acquired as a survival strategy and establishment, the rapid development of their roots after germination, allowing their establishment in areas subject to water stress.

Again, lower temperatures led to lower development, with reduced seedling growth. Gordin et al. (2012) also reported small growth of Guizotia abyssinica Cass at lower temperatures. Temperatures below or above optimum expose seedlings for longer periods to adverse factors, leading, for example, to biomass reduction, mainly between tropical and subtropical species. The extent of the damage depends, among other reasons, on the initial seed water content, which would affect the recalcitrant seeds more strongly (BEWLEY et al., 2013).

Normally the optimal temperature for cell division is approximately $30^{\circ} \mathrm{C}$ for most species and the results obtained for Eugenia stictopetala confirmed that this temperature was also the most adequate for its germination and initial growth. Oliveira and Pereira (2014) and Oliveira et al. (2017), evaluating the best conditions for seed germination and initial formation of Guibourtia hymenaefolia (Moric.) J. Léonard seedlings, collected in areas of Serra de Bodoquena and Sapindus saponaria L., obtained in Pantanal, Mato Grosso also showed that the temperature of $30^{\circ} \mathrm{C}$ was one of the most suitable for the evaluated species.

In relation to storage, the data indicated a loss of vigor, with a reduction in the germination rate with the plastic container being the most suitable. Considering that a reduction of $8 \%$ of water in the stored seeds occurred on average, this situation affected negatively the germination, because the best physiological vigor occurs when the seeds have higher water content and their loss, after storage, leads to a decrease in germination. The decrease in germination was also observed in seeds E. brasiliensis Lam. (Kohama et al., 2006), also intolerant of desiccation, where the gradual loss of water content led to a continuous reduction in germination. The same authors demonstrated that the best seeds response after storage was at constant temperature (cold chamber), unlike the results observed in this work, where the best percentage was observed at ambient temperature, demonstrating that species of the same genus can present different behavior in relation to storage requirements.

The semipermeable plastic packaging allowed a lower gas exchange and humidity with the environment, being the most suitable for the seeds conservation of recalcitrant characteristics that require aeration, such as Eugenia stictopetala. Therefore, higher germination rates of the seeds conditioned at ambient temperature may be related to the seed hygroscopic balance with the medium in which they were conditioned, reached by a lower seeds contact with the atmospheric water vapor and its oscillations. 


\section{CONCLUSION}

The analyzes carried out lead to the conclusion that:

- The seeds of Eugenia stictopetala have a recalcitrant characteristic, with high water content; their best germination rate and seedling formation was obtained at a temperature of $30^{\circ} \mathrm{C}$, with storage providing water loss and a significant reduction in the number of germinated seeds.

\section{ACKNOWLEDGMENT}

The authors are grateful to the National Council of Scientific and Technological Development (CNPq) for providing the Scientific Start-up Grant (PIBIC) and Produtividade em Pesquisa (PQ2) and Coordination of Improvement in Higher Education Personnel (CAPES) for scholarship. We would also like to thank the Foundation for the Development of Educatio, Science and Technology in Mato Grosso do Sul State (FUNDECT). Finally, we extend our thanks to Anhanguera-Uniderp University for funding the Interdisciplinary Reseach Group (GIP project).

\section{REFERENCES}

BEWLEY, J. D.; BRADFORD. K.; HILHORST, H.; NONOGAKI, H. Seeds: physiology of development, germination and dormancy. 3rd ed. New York: Springer, 2013, 392 p.

BRANCALION, P. H. S.; MARCOS FILHO, J. Distribuição da germinação no tempo: causas e importância para a sobrevivência das plantas em ambientes naturais. Informativo ABRATES, Londrina, v. 18, n. 1, 2, 3, p. 11-17, 2008.

BRANCALION, P. H. S.; NOVEMBRE, A. D. L. C.; RODRIGUES, R. R. Temperatura ótima para germinação de sementes de espécies arbóreas brasileiras. Revista Brasileira de Sementes, Londrina, v. 32, n. 4, p. 15-21, 2010.

BRASIL. 2009. Ministério da Agricultura, Pecuária e Abastecimento. Regras para análise de sementes. Brasília: Secretaria de Defesa Agropecuária. Mapa/ACS, 399 p.

CARDOSO, V. J. M. Uma análise termobiológica da germinação. Naturalia, Rio Claro, v. 32, p. 35-52, 2009.

COSTA, K.; PINTO, L. V. A.; MORAIS, V. S. P.; OLIVEIRA, C. L.; BARRETO, R. D. Germinação de sementes inteiras e fracionadas para a seleção de matrizes de uvaia. Revista Agrogeoambiental, Pouso Alegre, v. 9, n. 3, p. 47-59, 2017.

DANNER, M. A.; CITADIN, I.; SASSO, S. A. Z.; SACHET, M. R.; AMBRÓSIO, R. Fenologia da floração e frutificação de mirtáceas nativas da floresta com araucária Revista Brasileira de Fruticultura, Jaboticabal, v. 32, n. 1, p. 291-295, 2010.

GOMES, J. P.; OLIVEIRA, L. M.; FERREIRA, P. I.; BATISTA, F. Substratos e temperaturas para teste de germinação em sementes de Myrtaceae. Ciência Florestal, Santa Maria, v. 26, n. 4, p. 285-293, 2016.

GORDIN, C. R. B.; MARQUES, R. F.; MASETTO, T. E.; SCALON, S. P. Q. Germinação, biometria de sementes e morfologia de plântulas de Guizotia abyssinica Cass. Revista Brasileira de Sementes, Londrina, v. 34, n. 4, p. 619-627, 2012.

KOHAMA, S.; MALUF, A. M.; BILIA, D. A. C.; BARBEDO, C. J. Secagem e armazenamento de sementes de Eugenia brasiliensis Lam. (grumixameira). Revista Brasileira de Sementes, Londrina, v. 28, n. 1, p. 72-78, 2006.

LIU, K.; BASKIN, J. M.; BASKIN, C. C.; BU, H.; DU, G.; MA, M. Effect of diurnal fluctuating versus constant temperatures on germination of 445 species from the Eastern Tibet Plateau. PLoS One, São Francisco, e69364, v. 8, p. 1-9, 2013.

LOPES, R. R.; FRANKE, L. B. Aspectos térmico-biológicos da germinação de sementes de cornichão anual sob diferentes temperaturas. Revista Brasileira de Zootecnia, Viçosa, v. 40, n. 10, p. 2091-2096, 2011.

NONOGAKI, H.; BASSEL, G. W.; BEWLEY, J. D. Germination still a mystery. Plant Science, Limerick, v. 179, n. 1, p. 574-581, 2010.

FLORESTA, Curitiba, PR, v. 49, n. 4, p. 869 - 876, out/dez 2019. 
OLIVEIRA, A. K. M.; PEREIRA, K. C. L. Efeito de diferentes temperaturas na germinação e crescimento radicular de sementes de jatobá-mirim (Guibourtia hymenaefolia (Moric.) J. Léonard). Ciência Florestal, Santa Maria, v. 24, n. 1, p. 111-116, 2014.

OLIVEIRA, A. K. M.; MOTA, C. M. G.; AGNES, D. C. Efeito de diferentes temperaturas na germinação de sementes e no crescimento inicial de plântulas de Miconia albicans (Melastomataceae). Revista Brasileira de Plantas Medicinais, Campinas, v. 16, n. 3, supl. I, p. 755-759, 2014.

OLIVEIRA, A. K. M.; SOUZA, J. S.; CARVALHO, J. M. B.; SOUZA, S. A.; BOCCHESE, R. A. Germinação de sementes e crescimento de Ormosia arborea em diferentes temperaturas e substratos. Gaia Scientia, João Pessoa, v. 10, n. 4, p. 262-271, 2016.

OLIVEIRA, A. K. M.; SOUZA, J. S.; CARVALHO, J. M. B.; OJEDA, P. T. A. Temperatura e substrato na germinação de sementes e no crescimento inicial de plântulas de Sapindus saponaria (Sapindaceae). Gaia Scientia, João Pessoa, v. 11, n. 1, p. 131-143, 2017.

PERIOTTO, F.; GUALTIERI, S. C. J. Germinação e desenvolvimento inicial de Campomanesia pubescens (DC.) O. Berg (Myrtaceae) em diferentes substratos. Ciência Florestal, Santa Maria, v. 27, n. 3, p. 743-752, 2017.

ROCHA, G. F.; FERREIRA, L. G.; FERREIRA, N. C.; FERREIRA, M. E. Detecção de desmatamento no bioma Cerrado entre 2002 e 2009: padrões, tendências e impactos. Revista Brasileira de Cartografia, Rio de Janeiro, v. 63 , n. 3, p. 341-349, 2011

SALOMÃO, N. A.; SILVA, J. C. S.; DAVIDE, A. C.; GONZALES, S.; TORRES, R. A. A.; WETZEL, M. M. V. S.; FIRETTI, F.; CALDAS, L. S. Germinação de sementes e produção de mudas de plantas do Cerrado. Brasília: Rede de Sementes do Cerrado, 2003, 96 p.

SILVA, C. V.; BILIA, D. A. C.; BARBEDO, C. J. Fracionamento e germinação de sementes de Eugenia. Revista Brasileira de Sementes, Londrina, v. 27, n. 1, p. 86-92, 2005.

SILVA, F. A. S.; AZEVEDO, C. A. V. The Assistat Software Version 7.7 and its use in the analysis of experimental data. African Journal of Agricultural Research, Abuja, v. 11, n. 39, p. 3733-3740, 2016. 